\title{
Fair value measurements of control premiums
}

Wessel M. Badenhorst

University of Pretoria

Department of Accounting, Faculty of Economic and Management Sciences, University of Pretoria, Pretoria, 0002, Republic of South Africa

E-mail: wessel.badenhorst@up.ac.za

Tel: +27 4203421

Fax: +27 3625142

Acknowledgements: Thanks to Petri Ferreira, Marna de Klerk, Lizette Kotze for their helpful comments and suggestions.

This paper has been published in Accounting Perspectives, 2014, vol. 13, pp. 173-188 


\section{Fair value measurements of control premiums}

Abstract: As the overview of the current state of research within this paper shows, the debate around fair value measurements is far from over. This paper analyses fair value measurement requirements in a controversial scenario, namely when a control premium exists. The analyses of the paper show that, while measurement rules around control premiums could have a material impact on fair value measurements and the financial statements as a whole, significant fair value measurement issues remain unresolved. The conclusion is that fair value measurements should include or exclude control premiums consistently. It is argued that including control premiums for all fair value measurements is the most faithful representation of the underlying economic phenomenon. This paper contributes to the fair value measurement debate by comparing the merits of alternative fair value measurements for control premiums and highlights an area where researchers, investors and other users should exercise caution when evaluating financial statements.

Keywords: Fair value; Control premium; IFRS 13; Measurement 


\section{Introduction}

The objective of this paper is to critically evaluate the fair value measurement requirements of IFRS 13, Fair Value Measurement (2011), effective January 2013, [hereafter: IFRS 13] in respect of controlling investments. This scenario has been selected, firstly because of the continued controversy around the fair value measurement thereof and secondly because existing knowledge provides insight into the real world impact these fair value measurements requirements are likely to have.

The controversy around fair value measurements of controlling investments arises because such fair value measurements could either include or exclude a control premium. This paper analyses the reasoning for the current fair value measurement requirements and finds a significant weakness therein. The analyses show that current fair value measurement requirements are inconsistent between listed and unlisted controlling investments as such investments have the same unit of account, but differing fair value measurement guidance. Furthermore, excluding control premiums from fair value measurements do not faithfully represent the underlying economic reality, as prior research finds actual control premiums paid average more than $40 \%$ (e.g. Betton et al., 2009). Consequently the paper concludes that a more faithful fair value measurement would include control premiums for both listed and unlisted controlling investments.

This paper contributes to the existing literature in several ways. Firstly, as highlighted by an overview of prior research in a later section, the debate on fair value measurement is far from over. As a result, the standard-setters’ latest attempt merits continued analysis. Secondly, prior academic research has tended to consider fair value measurements as a concept. With the notable exception of studies around the fair value hierarchy (Song et al., 2010) and different recognition requirements (So \& Smith, 2009), few academic papers have evaluated different approaches to determining fair value measurements for the same item. 
Thirdly, the analysis of the measurement requirements gives insight into preparing or using financial statements that incorporate fair value measurements of controlling investments. Lastly, the paper suggests an alternative to the current fair value measurement rules for control premiums. This raises potential research questions and provides a theoretical basis for future empirical research into fair value measurements of controlling investments.

The rest of the paper is set out as follows: firstly the definition of fair value is considered, thereafter prior research around fair value and the implications thereof, followed by a description of the research methodology and approach of this paper. Subsequently the fair value measurement requirements for control premiums are evaluated after which the last section summarises and concludes the paper.

\section{Definition of fair value}

Prior researchers have long debated what an appropriate definition of fair value should be. Barth and Landsman (1996), for example, suggest that fair value may be defined with reference to entry values, exit values or values in use and conclude that the definition used by the FASB reflects an exit value. The definition adopted by the IASB is closely aligned with that of the FASB and reflects the success of the standard-setters in increased convergence. As a result, the fair value definition adopted by the IASB also reflects an exit value, which is explicitly stated in IFRS 13.2. The fair value measurements utilised by the IASB represent market-based measurements, which do not include the intentions of the entity (IFRS 13.3). Furthermore, a fair value measurement should reflect the assumptions that market participants would use when pricing an asset or liability (IFRS 13.3). Therefore, in this paper, a fair value measurement is considered to be non-market based if it incorporates either the intentions of the entity or incorrectly incorporates assumptions that market participants would use when pricing an asset or liability. In summary, the definition of fair value in IFRS 13 is accepted as a given, against which specific applications should be weighed. 


\section{Prior research}

\section{Empirical research}

Empirical research on the use of fair value measurements generally form part of the branch of research referred to as the ‘value-relevance’ literature. This branch of research investigates associations between accounting amounts and share prices (Barth et al., 2001). Valuerelevance studies tend to regress share prices (or returns) on particular fair value measurements of interest (or changes therein). An association between the fair value measurement being considered and share prices provides evidence of the decision-usefulness of the fair value measurement as value-relevance tests are joint tests of relevance and reliability (Barth et al., 2001). Because the objective of financial statements per the Conceptual Framework (2010) puts improved decision-making at its heart, evidence of decision-usefulness is of particular importance. In contrast to some of the theoretical research discussed later, empirical research generally reaches conclusions that place the use of fair value measurements in a favourable light.

Fair value measurements have been found to be value-relevant for assets as diverse as brand names (e.g. Barth et al., 1998) and the financial instruments of banks (e.g. Barth et al., 1996). Similar findings have also been noted for fair value measurements of non-pension post-retirement liabilities (e.g. Choi et al., 1997) and financial liabilities (e.g. Barth et al., 2008) ${ }^{1}$. In addition, such studies have found fair value measurements to remain valuerelevant even as estimation uncertainty increases between levels within the fair value hierarchy (cf. Song et al., 2010). Research has also revealed that recognising fair value adjustments in profit or loss, as opposed to directly in equity, increases their value-relevance (So \& Smith, 2009).

For a more detailed review of the findings of various value-relevance papers, refer to Holthausen and Watts (2001) and Barth et al. (2001). 
It is therefore clear that empirical studies generally tend to find a positive role for fair value measurements, defined as exit values per the current FAS No. 157 (2006) and IFRS 13. From this research therefore, it can be seen that prior research considers fair value measurements, as implemented in financial reporting practice, to lead to both relevant and faithfully represented information. However, despite the findings of empirical research, some theoretical research has tended to view fair value measurements in a negative light. This may be due to a differing perception of the users of financial statements (empirical research focuses on equity investors) or the objective of financial reporting. Indeed a few theoretical papers explicitly state their differing views in these respects. Some findings of theoretical research are discussed in greater detail in the section that follows.

\section{Theoretical research}

A significant part of research on the theoretical desirability of fair value measurements is of a critical nature. For example, Penman (2007) argues that fair values as exit values is a workable idea in theory, but that implementation problems suggest that the blanket use of fair values is undesirable. Specifically, Penman (2007) suggests that fair values are useful where the relationship between exit prices and fair value to shareholders is one-to-one, whereas the use of fair values present many problems when the value of a firm's assets lies in the execution of its business plan. Whittington (2008) argues that the use of fair value measurements would require the existence of a perfect market, whence these fair values could be obtained and that non-market based measurements may be essential (and even desirable) elements in financial reporting. Similarly Hitz (2007) suggests that fair value measurement has a theoretical case in respect of financial instruments, but that fair value measurements of non-financial assets have much weaker theoretical support. 
As the objective of financial statements per the Conceptual Framework (2010) is to improve decision-making, fair value measurements in financial statements should be decision-useful. Therefore, another branch of research has focused on the potential decisionusefulness of fair value measurements. In this respect some authors suggest that the use of fair value measurements is inappropriate even in theory; as such measurements are not decision-useful in their opinion. For example, Ronen (2008) suggests that fair value measurements do not provide information about the magnitude of future cash flows of a firm, which information, the author argues, is the basis of the fair value of the firm to its investors. The author suggests that historical cost accounting is in fact more forward-looking (and therefore decision-useful) than fair value accounting, as the matching of historical transactions have greater predictive value than fair value measurements at a point in time.

Another theoretical criticism of the use of fair value measurements often aired is that it leaves no room for conservatism, which is likely to be of particular value and interest to debt investors (as opposed to equity investors). For example, Holthausen and Watts (2001) contend that fair value accounting suggests that the primary purpose of the statement of financial position is that of valuation of the firm, where contracting purposes may require greater conservatism than fair value measurements are prepared to allow. These sentiments are continued in Watts (2003) who suggests that conservatism in financial reporting is an important attribute of financial statements for contracting, litigation risk and tax reasons as conservative measures tend to be based on information that is directly verifiable. The author therefore argues that fair value measurements with their focus on 'neutrality' will open the way to problems which conservatism evolved to address, specifically in relation to fraud risk.

More recently, Kothari et al. (2010) contend that the objective of Generally Accepted Accounting Principles is not solely decision-usefulness as held by standard-setters. They argue that assessing the stewardship of management is an essential role of financial reporting 
and that this assessment requires a greater degree of verifiability and conservatism than fair value measurements are able to provide when liquid secondary markets do not exist. Similarly Biondi et al. (2012) argue that reliability should form the focus of measurement bases and that flows may sometimes prove more reliable measurements bases than fair values (balances), suggesting that fair value measurement should not be the exclusive focus of standard-setters.

However, despite such criticism, fair value measurements are increasingly being used in financial reporting. Power (2010) suggests that fair values gained traction because of widespread acceptance, rather than technical superiority. He argues that the need to solve the accounting problems for derivatives provided a catalyst to spread fair value accounting to other financial instruments, for example. An unflattering comment by Power (2010) is that fair value measurements became part of the professional identity of standard-setters, rather the considered decision it has been made out to be. This echoes findings by Parker (2007) that recent accounting research has tended to focus on narrow areas, limited by acceptable research problems and research methodologies. In other words, such papers suggest that use of fair values and research around them became self-reinforcing over time.

Not all theoretical findings have proven as negative relating to fair value measurement as those immediately above. Barlev and Haddad (2007) argue, for example, that only under a fair value measurement regime will financial reporting become comparable across countries, i.e. fair value measurement by itself enhances the comparability of financial reporting. Cairns (2006:19-20) suggests that fair value measurements incorporate notions that were part of national accounting standards and long-standing principles in financial reporting. He suggests that those opposed to the increased use of fair value measurements were not previously applying national accounting standards in the spirit in which they were intended. 
Furthermore, a large number of theoretical papers do support the use of fair value measurements for at least some assets (e.g. Penman, 2007; Hitz, 2007).

The standard-setters’ own theoretical analyses have also been broadly positive regarding the use of fair value measurements in financial reporting. For example, in FASB Statement of Accounting Concepts No. 7 (2008) it is noted that recognition for accounting purposes is usually triggered by cash transactions in the marketplace. These actual exchange prices (cash exchanged) usually reflect fair values in the absence of evidence to the contrary, which all accountants are willing to recognise. Consequently the Statement concludes that all present value measurements should essentially reflect what the value of a market-based cash exchange transaction (i.e. fair value) would be at the measurement date. Another example is the IASB’s Discussion Paper: Measurement Bases for Financial Accounting - Measurement on Initial Recognition (2005), where it is argued that the discipline of markets results in a measurement free from entity-specific expectations, which make fair value measurements especially relevant. Given the support from empirical research and theoretical papers such as these, perhaps it is not entirely surprising that standard-setters have tended to ignore some of the more critical voices in this regard.

What is clear from the review of prior theoretical research is that some research is critical of use fair value measurements, but that such findings are not universal. As a result, the recent global financial crisis has increased the self-belief of critics and led others to reconsider the findings around fair value measurements. Some research findings around fair values and the recent financial crisis are considered in the section that follows.

\section{Fair value and the financial crisis}

The global financial crisis of 2007 to 2009 has revived the debate around the use of fair values in accounting as a potential source or exacerbating agent of the financial crisis. In this 
respect early research has been mainly analytical. Laux and Leuz (2009), for example, suggest that implementation issues may have arisen from the use of fair value accounting, but that the requirements of the accounting standards themselves are unlikely to have caused the problems that critics link to fair value accounting. In a similar vein Barth and Landsman (2010) argue that fair value accounting played little or no role in the financial crisis and suggest that the main problem may have been a lack of transparency in disclosures surrounding asset securitisations and derivatives. In support of such analytical research, Badertscher et al. (2012) focus on the aggregate effect of fair value accounting losses in an empirical study and suggest that these had a minimal impact on regulatory capital, while any pro-cyclical effects of fair value accounting appear to be economically insignificant. However, in contrast Bhat et al. (2011) find that, although fair value losses most likely did not have economy-wide significance, it resulted not only in pro-cyclical selling of mortgagebacked securities by specific banks, but also had a measurable economic effect on the banks concerned. Such findings suggest that individual holders of assets during the financial crisis based decisions on fair value measurements, as empirical research prior to the crisis found that they do. In the context of this paper therefore, fair value measurements appear to remain relevant even when a financial crisis and resulting illiquidity causes fair value measurements to be less transparent. In this context, Bushman and Landsman (2010) argue that financial crises have led to simultaneous changes in regulatory and accounting requirements. This suggestion highlights the potential effect of political pressure in the aftermath of a crisis, but also that the debate around the relevance and faithful representation of fair value measurements is ongoing. 


\section{Summary of prior research and the context of this paper}

In summary, empirical papers generally find that fair value measurements are value-relevant and are therefore used by investors in decision-making, while the findings of theoretical papers tend to be more ambiguous. One reason for the difference appears to be that empirical papers tend to focus on the decision-usefulness of fair value measurements for equity investors while theoretical papers have a broader focus. Another is that empirical papers tend to assess the value-relevance of an existing fair value measurement and not whether it can be improved. Furthermore, as an analysis of research findings around the financial crisis of 2007 to 2009 reflects, the debate surrounding the use of fair value measurements is still evolving.

In the context of an unsettled debate, the standard-setters' latest stab at fair value measurement guidance therefore deserves continued scrutiny. In particular, prior research, whether empirical or theoretical, tends to consider the appropriateness of fair value measurement as a single concept. Little academic research has previously focused on comparing different approaches to determining fair value measurements for the same item, with the notable exception of studies comparing the value-relevance of fair value measurements between levels in the fair value hierarchy (e.g. Song et al., 2010) and those comparing different recognition requirements (e.g. So \& Smith, 2009). This paper therefore contributes to the existing literature by comparing different approaches to determine fair value measurements for the same item. This comparison takes place in the context of the latest fair value measurement guidance, using the methodology and approach discussed in the next section.

\section{Research methodology and approach of this paper}

This paper considers a specific fair value measurement scenario, namely measuring fair value for a controlling investment. This scenario has been selected for several reasons. Firstly, a 
consideration of alternatives for all individual fair value measurement requirements is a task beyond a single research paper. Secondly, this scenario has detailed application guidance in IFRS 13, which eliminates ambiguity of the standard-setters' intentions to a certain degree. In addition, IFRS 13 also includes significant justification for the decisions made with regard to control premiums. This is because this is a controversial fair value measurement, generating debate during the standard-setting process. As a result, the outcome of this process is also worthy of further discussion and analysis. A last consideration in selecting this scenario was that prior research gives significant insight into the likely implications of the latest fair value measurement guidance, allowing existing knowledge to facilitate the analysis.

The discussion of the scenario in this paper starts off with a basic background discussion of the current fair value measurement guidance, after which the fair value measurement requirements in IFRS 13 are analysed using the following structure:

1. Are the differences between current fair value measurement requirements and plausible alternatives likely to be material?

The controversy around the scenario selected for analysis would suggest that this fair value measurement requirement has a material impact. However, as a starting point for its evaluation, this paper provides additional support in this respect, with reference to prior research.

2. What was the IASB's reasoning behind the current requirements?

A brief analysis of the IASB's reasoning for the current fair value measurement requirements as set out within IFRS 13 is provided. This provides the background for the subsequent evaluation of the measurement guidance. 
3. How does the reasoning behind the current requirements measure up?

The IASB's reasoning is critically evaluated. The arguments are reviewed for internal logic, consistency and against the qualitative characteristics in the Conceptual Framework (2010).

4. How well do the current requirements meet the definition of fair value in IFRS 13? In this part of the analysis, the paper considers whether applying the current fair value measurement guidance leads to a fair value measurement that is (i) an exit value, (ii) market-based and (iii) bias-free, i.e. the measurement should not reflect the intentions of the entity concerned (IFRS 13.2-3). For the purposes of this paper this is interpreted quite narrowly and it is considered that for a fair value measurement to be market-based, the measurement should be the same regardless of who the reporting entity is.

5. How widespread will the impact of the fair value measurement requirements be?

It is considered whether the fair value measurement requirements will affect a large number of entities or merely a small subset.

6. What are the alternatives to the current measurement requirements?

In addition to providing suggestions of and supporting arguments for an alternative fair value measurement base, this part of the analysis also provides the paper's detailed conclusions.

In the section which follows, the fair value measurement requirements around controlling investments are evaluated using the approach outlined above.

\section{Analyses of fair value measurement applications to controlling investments}

The debate around fair value measurements of controlling investments is caused by the presence of control, which causes a controlling investment in an entity to have a greater open market value than an otherwise identical, but non-controlling, investment. In other words, 
control has a value independent of the basic economic value of the underlying asset, which reflects the ability of the investor to direct the activities of the investee to its own advantage. The question is whether fair value measurements should include or exclude the value of control (i.e. the control premium).

The current IFRS 13 does not contain a universal decision. IFRS 13.69 firstly requires an entity to include control premiums in fair value measurements, but then prohibits any adjustment of level one fair value measurements (i.e. fair value measurements based on quoted market prices). To facilitate an understanding of the implications of IFRS 13.69, an example is set out in Table 1. This example shows that the fair value of a non-controlling investment in a listed and unlisted entity would be identical (\$6 000) once the marketability and risk discount associated with the unlisted entity (\$2 100) is controlled for. In other words, the resulting fair value measurements are still comparable and relevant for decision-making, as the difference faithfully represents increased economic risk.

Table 1: The fair value measurement of listed and unlisted controlling investments

\section{Listed}

Number of shares in issue

Market price per share of the listed entity / similar listed entity

Assumed marketability and risk discount for unlisted entity

Assumed control premium for controlling investment

Fair value of a $60 \%$ non-controlling investment

Marketability and risk discount for unlisted entity

Fair value of a $60 \%$ non-controlling investment

Control premium

Fair value of a $60 \%$ controlling investment per IFRS 13
1000

$\$ 10$

$\mathrm{n} / \mathrm{a}$

$45 \%$

\begin{tabular}{|c|c|}
\hline${ }^{(1)} \$ 6000$ & $\begin{array}{r}{ }^{(1)} \$ 6000 \\
{ }^{(2)}(\$ 2100)\end{array}$ \\
\hline$\$ 6000$ & $\$ 3900$ \\
\hline (4)_ & ${ }^{(3)} \$ 1755$ \\
\hline$\$ 6000$ & $\$ 5655$ \\
\hline
\end{tabular}

(1) $1000 \times 10 \times 60 \%=6000$

(2) $6000 \times 35 \%=2100$

(3) $3900 \times 45 \%=1755$

(4) IFRS 13.69 prohibits the adjustment of the quoted price of the listed entity with control premiums. Applying the control premium would have resulted in an increase in fair value of the investment in the listed entity of \$2 700 and thus a total fair value measurement of \$8 700 . 
The example shows that, for a listed entity, the IFRS 13 fair value measurement of a controlling investment would be equal to the fair value of an identical non-controlling investment in the same entity. However, the fair value measurement of a controlling investment in an unlisted entity increases compared to an identical non-controlling investment in the same entity. The fair value measurements for listed and unlisted controlling investments now differ based on underlying economic risks (such as marketability) as well as a decision on when the control premium may be measured. A control premium exists economically for both investments, yet applying IFRS 13.69 means that the fair value measurement of the listed investment does not include this, while that of the unlisted investment does.

This anomaly in the current measurement requirements of IFRS 13, highlighted by the example in Table 1, is discussed and analysed in the subsections which follow.

\section{Would the impact of applying a control premium (or omitting it) be material?}

Prior research gives a clear indication that control premiums are material. For example, Betton et al. (2009) document an average control premium for all acquisitions of US public firms between 1973 and 2002 of 46,1\%, with largely similar premiums paid by public and private acquirers. However, actual control premiums paid also depend on the nature of the acquirer's offer. In this respect Betton et al. (2009) document an average 60,9\% control premium in hostile bids for US public firms between 1973 and 2002, while friendly bids attracted a premium of only $45,1 \%$ during the same period. However, regardless of the nature of the bid, control premiums appear to be above $40 \%$ in the US and to exist independently from specific acquirers or transactions. Consequently, the impact of applying a control premium (or omitting it) clearly has a material impact on fair value measurements of controlling investments and potentially on the financial statements as a whole. 


\section{What was the IASB's reasoning behind the current requirements?}

The reasoning behind the IASB's decision is set out in IFRS 13.BC152 - BC159. In brief, the core issue is whether or not individual financial instruments (excluding a control premium) or an entity's entire holding (including a control premium) should be the basis of fair value measurements of controlling investments. In other words, the main concern is what the unit of account for fair value measurements should be. The IASB's stance is summarised in the statements that the standard should address 'how to measure fair value and not what is measured at fair value' (IFRS 13.BC155) and that the application of premiums 'must be consistent with the unit of account in the IFRS that requires or permits the fair value measurement' (IFRS 13.BC158). In other words, other standards determine what the unit of account is and IFRS 13 focuses solely on measuring the fair value of this unit of account.

\section{How does the reasoning behind the current requirements measure up?}

The standards permitting or requiring fair value measurement of controlling investments are IAS 27 (2011) and IFRS 10 (2012). These standards refer such fair value measurements to the financial instruments standards. The unit of account for financial instruments is individual instruments. Therefore controlling investments are comprised of individual instruments. ${ }^{2}$

The IASB notes that ignoring control premiums imply that individual financial instruments (rather than entire holdings) are being measured (IFRS 13.BC155). This is in line with the unit of account in the aforementioned standards. However, if ignoring control premiums imply that individual financial instruments are being measured at fair value, then the opposite is also true. Adding control premiums to fair values of unlisted controlling investments (IFRS 13.69) measures them as single holdings. This is not in line with the unit

\footnotetext{
2 In this respect it is important that none of the requirements in these standards distinguish
} between listed and unlisted investments. 
of account in the applicable standards nor the unit of account used for listed controlling investments. This means that the requirements for measuring control premiums are internally illogical. If IFRS 13 does not determine or alter the unit of account, listed and unlisted controlling investments should not have different fair value measurement requirements, as their unit of account is the same in the standards requiring or permitting the fair value measurement.

\section{How well do the current requirements meet the definition of fair value in IFRS 13?}

When considering fair value measurements of listed controlling investments against the definition of fair value, the biggest concern is that the fair value measurement would not represent actual prices at which the asset would be transferred. If control premiums are ignored, the fair value measurement of the investment will significantly understate the transfer price of the controlling investment, considering the average size of control premiums (cf. Betton et al., 2009). In contrast, fair value measurements of unlisted controlling investments would represent actual prices at which the asset could be transferred and thereby meet the definition of fair value. It is therefore not possible to argue that both Level 1 fair value measurements (ignoring the control premium) and Level 3 fair value measurements (including the control premium) equally meet the definition of fair value at a theoretical level. This is true, even when potential trade-offs between qualitative characteristics are considered, as the fundamental equivalent nature of controlling investments imply that these trade-offs should have resulted in an identical outcome.

A second concern with the definition of fair value is that any fair value measurement should be market-based and not depend on the decisions of the entity. Market participants are willing to pay a premium for control, regardless of who the current owner is. Control premiums are therefore available to any reporting entity, regardless of the entity's reputation 
or whether or not the controlling investment is quoted. By requiring control premiums to be ignored in fair value measurements of quoted investees, the decisions of the entity (whether or not to list the investee) is brought into the fair value measurement. Based on prior research findings (cf. Betton et al., 2009) this decision will have a significant impact on the fair value measurement of the investment. If the fair value measurement were truly market-based and bias-free, decisions of the entity would have a significant impact on outcomes.

\section{How widespread will the impact of the fair value measurement requirements be?}

Controlling investments have traditionally been consolidated in financial statements with fair value measurements restricted to separate financial statements. As many jurisdictions require an entity to present consolidated financial statements only, it would be easy to dismiss the impact of fair value measurement requirements for controlling investments as insignificant. However, an important change to IFRS 10, Consolidated Financial Statements (2012), compels investment entities to measure controlling investments at fair value. Therefore the impact of the fair value measurement requirements is far more widespread than may initially be apparent.

\section{What are the alternatives to the current measurement requirements?}

An alternative fair value measurement should either universally accept the unit of account of other standards for controlling investments (i.e. individual instruments) or change the unit of account to single holdings for all controlling investments. The first alternative would consistently exclude control premiums from fair value measurements of controlling investments, while the latter would consistently include control premiums in all such measurements. 
The most important factor to decide between the measurement alternatives is faithful representation. ${ }^{3}$ In this respect, consider that an unlisted investee decides to list. An immediate consequence for an investor would currently be that the fair value of a controlling investment must be amended to exclude the control premium (IFRS 13.69), even though control premiums are regularly paid to obtain control of listed entities (cf. Betton et al., 2009). When the act of listing is considered in isolation, the fair value measurement requirements appear to attribute a negative value to this, by eliminating a previously significant component from the fair value measurement of the controlling interest. This is an unfaithful representation of the economic reality, which is that the control premium still exists and could potentially be measured.

A factor to consider in this respect is the verifiability of measuring control premiums. This appears to be a concern of a significant group within the accounting and business community. Indeed the IASB notes that respondents favouring the measurement of a controlling investment as individual financial instruments 'understood the boards' concerns about verifiability within Level 1' (IFRS 13.BC155). However, another comment by the IASB implies that measuring controlling investments as individual financial instruments does not reflect economic reality as 'entities do not typically exit a position on an individual instrument basis’ (IFRS 13.BC155). In other words the economic reality is based on the entity’s investment as a whole, which arguably reflects faithful representation.

The counterargument to this is that not all economic phenomena can be perfectly faithfully represented. Differences in control premiums under different circumstances (cf. the earlier materiality discussion) might mean that control premiums are difficult to determine in practice and may be so unverifiable that they ought not to be measured at all. However, a user

3 Relevance is not as important as faithful representation for this discussion, because different specifications of the same measurement base (fair value) are being considered, rather than different measurement bases (e.g. cost versus fair value). 
can easily verify the fair value (excluding the control premium) of a listed controlling investment with little cost, where IFRS 13.69 requires control premiums to be ignored. At the same time, control premiums are currently taken into account where the fair value of any stake (whether controlling or non-controlling) is difficult to determine and verify. In this respect, the verifiability of control premiums is surely verifiable to the same degree (if not more) for listed investments compared to unlisted investments. Therefore, if control premiums are currently sufficiently verifiable for financial reporting purposes in the case of unlisted controlling investments, they must be likewise sufficiently verifiable in the case of listed controlling investments.

As stated at the beginning of this section, any alternative fair value measurement requirement should be applied consistently across controlling investments as they have the same unit of account. However, consistency is also important as it would enhance comparability between investors’ financial statements and different controlling investments of an investor. Although comparability in the Conceptual Framework (2010) is not uniformity, an important principle is that comparability ensures that like things do not appear unlike in the financial statements. Controlling investments are conceptually the same and have the same unit of account regardless of whether or not they are listed. Therefore there is also a real argument that comparability is being undermined by ignoring control premiums for some controlling investments but not for others.

Another significant question is what the level of knowledge of investors is expected to be. There is a strong argument that financial statements of different entities measuring controlling investments at fair value can only be compared by someone with a comprehensive understanding of IFRS 13. This is because significant adjustments may be required for comparisons where controlling investments of one entity are listed, while those of the other are not. As comparisons between entities are an important part of investment decisions 
(cf. Conceptual Framework, 2010: QC20), the impact on understandability is not an inconsequential concern. Although the Conceptual Framework (2010) suggests that advice may be necessary to understand 'complex economic phenomena’ (Conceptual Framework, 2010: QC32), the question is whether a controlling investment in another entity is sufficiently complex that the assistance of an advisor should be essential. Because of the pervasive occurrence of control in practice, there is a strong argument against this.

In summary, considering that prior research clearly shows that control premiums exist economically, it would appear that the most faithful representation of this economic reality would be to include control premiums in fair value measurements of all controlling investments. This point would be moot if the fair value of control premiums could not be faithfully represented or concerns around verifiability of such measurements were significant. However, current fair value measurements include control premiums for unlisted controlling investments, which imply that they can be faithfully represented. Furthermore, control premiums are currently included where independent verifiability is weakest. Therefore, adding a control premium where verifiability is fundamentally less of a concern (users can assess the reasonability of the fair values of listed controlling investments with ease and little cost) does not appear to be at odds with currently accepted risks in fair value measurements.

Including control premiums represent potential transfer values more faithfully and therefore results in more relevant information for decision-making, In addition, the current measurement requirements cause comparability and understandability difficulties, while including control premiums in the fair value measurements of all controlling investments would not impact on the current level of verifiability within existing fair value measurement requirements. Consequently, the most appropriate alternative to the current measurement requirements would be to include control premiums in the fair value measurements of all controlling investments, whether listed or unlisted. 


\section{Summary and conclusion}

This paper considers fair value measurement guidance on control premiums. The analysis of the paper suggests that the fair value measurement guidance currently contained in IFRS 13 assumes different units of account for listed and unlisted controlling investments. At best this guidance is internally illogical and worst results in fair value measurements of listed controlling investments that are not faithful representations of the underlying economic reality. As the impact of ignoring control premiums for some controlling investments is also likely to be material, it is suggested that improved fair value measurement guidance would universally require control premiums to be included in fair value measurements of controlling investments. This alternative measurement requirement provides suggestions for future research, whereby the alternative fair value measurement base could be compared to IFRS 13 fair value measurements to empirically investigate the theoretical analyses of this paper.

\section{References}

Badertscher, B.A., Burks, J.J. \& Easton, P.D., 2012. A convenient scapegoat: fair value accounting by commercial banks during the financial crisis. Accounting Review, 87(1):59-90.

Barlev, B. \& Haddad, J.R., 2007. Harmonization, comparability and fair value accounting. Journal of Accounting, Auditing and Finance, 22:493-509.

Barth, M.E., Beaver, W.H. \& Landsman, W.R., 1996. Value-relevance of banks’ fair value disclosures under SFAS No. 107. Accounting Review, 71(4):513-537.

Barth, M.E. \& Landsman, W.R., 1996. Fundamental issues related to using fair value accounting for financial reporting. Accounting Horizons, 9(4):97-107.

Barth, M.E., Clement, M.B., Foster, G. \& Kasznik, R., 1998. Brand values and capital market valuation. Review of Accounting Studies, 3:41-68.

Barth, M.E., Beaver, W.H. \& Landsman, W.R., 2001. The relevance of the value relevance literature for financial accounting standard setting: another view. Journal of Accounting and Economics, 31:77-104. 
Barth, M.E., Hodder, L.D. \& Stubben, S.R., 2008. Fair value accounting for liabilities and own credit risk. Accounting Review, 83(3):629-664.

Barth, M.E. \& Landsman, W.R., 2010. How did financial reporting contribute to the financial crisis? European Accounting Review, 19(3):399-423.

Bhat, G., Frankel, R. \& Martin, X., 2011. Panacea, Pandora’s Box or placebo: feedback in bank mortgage-backed security holdings and fair value accounting. Journal of Accounting and Economics, 52:153-173.

Betton, S., Eckbo, B.E. \& Thorburn, K.S., 2009. Merger negotiations and the toehold puzzle. Journal of Financial Economics, 91:158-178.

Biondi, Y., Glover, J., Jamal, K., Ohlson, J.A., Penman, S.H., Sunder, S. \& Tsujiyama, E., 2012. Some conceptual tensions in financial reporting. Accounting Horizons, 26(1): $125-133$.

Bushman, R. \& Landsman, W.R., 2010. The pros and cons of regulating corporate reporting: a critical review of the arguments. Accounting and Business Research, 40(3):259-273.

Cairns, D., 2006. The use of fair values in IFRS. Accounting in Europe, 3(1):5-22.

Choi, B., Collins, D.W. \& Johnson, W.B., 1997. Valuation implications of reliability differences: the case of non-pension post-retirement obligations. Accounting Review, 72(3):351-383.

FASB, 2006. Statement of Financial Accounting Standards No. 157, Fair value measurements. Norwalk: Conn. FASB.

FASB, 2008. Statement of Financial Accounting Concepts No. 7, Using Cash Flow Information and Present Value in Accounting Measurements. Norwalk: Conn. FASB.

Hitz, J., 2007. The decision usefulness of fair value accounting - a theoretical perspective. European Accounting Review, 16(2):323-362.

Holthausen, R.W. \& Watts, R.L., 2001. The relevance of the value-relevance literature for financial accounting standard setting. Journal of Accounting and Economics, 31:3-75. IASB, 2005. Discussion paper: measurement bases for financial accounting - measurement upon initial recognition. November, London, IFRS Foundation.

IASB, 2010. Conceptual framework for financial reporting. September, London. IFRS Foundation.

IASB, 2011. IAS 27, Separate financial statements. May, London. IFRS Foundation. IASB, 2011. IFRS 13, Fair value measurement. May, London. IFRS Foundation. 
IASB, 2012. IFRS 10, Consolidated financial statements. September, London. IFRS Foundation.

Kothari, S.P., Ramanna, K. \& Skinner, D.J., 2010. Implications for GAAP from an analysis of positive research in accounting. Journal of Accounting and Economics, 50:246286.

Laux, C. \& Leuz, C., 2009. The crisis of fair-value accounting: Making sense of the recent debate. Accounting, Organizations and Society, 34:826-834.

Parker, L.D., 2007. Financial and external reporting research: the broadening corporate governance challenge. Accounting and Business Research, 37(1):37-54.

Penman, S.H., 2007. Financial reporting quality: Is fair value a plus or a minus? Accounting and Business Research, Special Issue: International Accounting Policy Forum: 33-44.

Power, M., 2010. Fair value accounting, financial economics and the transformation of reliability. Accounting and Business Research, 40(3): 197-210.

Ronen, J., 2008. To fair value or not to fair value: a broader perspective. Abacus, 44(2):181208.

So, S. \& Smith, M., 2009. Value-relevance of presenting changes in fair value of investment properties in the income statement: evidence from Hong Kong. Accounting and Business Research, 39(2):103-118.

Song, C.J., Thomas, W.B. \& Yi, H., 2010. Value relevance of FAS No. 157 fair value hierarchy information and the impact of corporate governance mechanisms. Accounting Review, 85(4):1375-1410.

Watts, R.L., 2003. Conservatism in accounting, part I: explanations and implications. Accounting Horizons, 17(3):207-221.

Whittington, G., 2008. Fair value and the IASB/FASB conceptual framework project: an alternative view. Abacus, 44(2):139-168. 